Владан Гавриловић

Универзитет у Новом Саду

Филозофски факултет

Одсек за историју
Оригиналан научни рад

примљено: 7. март 2013

прихваћено: 1. октобар 2013

\title{
ВЕЛИКА СЕОБА СРБА КАО МИГРАЦИОНИ ТАЛАС У ВРЕМЕ ВЕЛИКОГ БЕЧКОГ РАТА*
}

Сажетак: Аутор у своме раду говори о различитим проценама броја досељеног српског народа за време Велике сеобе 1690. године. Највећи проблем који ни до данас није у потпуности разрешен у оквиру историјске науке је везан за то што поједини извори наводе веома велики број породица, које су крајем XVII века у српском друштву имале најмање седам до десет чланова домаћинства, што је битно увећавало број досељених лица. На основу тога бројке о досељеним Србима у време Сеобе варирају од 40.000 до близу 500.000 људи. Аутор износи овај проблем и досадашње ставове српске историографије о њему.

Кључне речи: Велика сеоба, Велики бечки рат, Срби, Хабзбуршка монархија.

После успеха аустријске војске у Угарској, Славонији и Западној Босни (1687/1688) тежиште ратних опрерација пренето је на Срем, Бачку и Ердељ, а потом на Србију и делове Бугарске. При томе је у њима било све веће учешће Срба, како оних затечених у Угарској тако и оних у Србији, који су жељно очекивали долазак царских трупа у њихове крајеве. То је до пуног изражаја дошло после заузимања Београда, Смедерева и Ужица у току септембра и октобра 1688. У погледу Смедерева Дворски ратни савет је средином октобра обавестио Царску дворску комору у Бечу да оно треба да послужи као предстража на Дунаву и да га помоћу „Раца и становника“ треба утврдити, као и да треба размотрити како се једни и други могу што више употребити за ратне заслуге царској војци. ${ }^{1}$ У погледу Ужица, део становника из околине града и са обале реке Мораве, одмах после ослобођења од Турака, њих око 6.000 душа, пребачен је преко Саве и насељене у опустошене крајеве Славоније и Срема. ${ }^{2}$ Такође су до краја 1688. од Срба, који су се са оружјем у

\footnotetext{
Текст је настао као фазни резултат рада на пројекту Војвођански простор у контексту европске историје (број 177002) Министарства просвете, науке и технолошког развоја Републике Србије. Такође, рад је настао на основу исписа почившег академика Славка Гавриловића (1924-2008), чије ће име остати урезано великим словима у српској историографији.

${ }^{1}$ Hoff kriegs archiv, Hoff finanz Ungarn (HKA, Hoff.Ungarn) r. N ${ }^{\circ}$ 325, October 1688, fol. 230.

${ }^{2}$ Алекса Ивић, Миграције Срба у Хрватску током 16, 17. и 18. столећа, Суботица 1923, 126.
} 
рукама прикључили царској војсци, биле делом створене српске чете (Razencompanien) под командом пуковника Павла Несторовића Деака, а делом Србиратници прикључени у славонску граничарску милицију дуж Саве. Тако је у току 1689. на простору од Земуна до Митровице било распоређено 2.299 хајдука-пешака и 1.035 хусара-коњаника под српским и немачким официрима.

После заузимања Београда 6. септембра 1688. године царска војска се ограничила за мање ратне операције у Србији у којој се народ под својим капетанима дизао и војевао против Турака, како у Западној Србији тако и са десне стране Мораве где су се сударали с Турцима који су долазили из Ниша. Пошто је Дворски ратни савет сматрао да Србе с те стране Мораве царска војска не може да заштити, својим генералима је фебруара 1689. наредио да их из околине Пожаревца, као и оне око Ужица, пресељавају у Срем и Славонију и да тако насељавају те опустошене области. ${ }^{3}$

Постављањем принца Лудвига Баденског за главнокомандујућег у Србији, Бечки двор је одлучио да његова војска и српске чете пођу дубље у Србију. У томе су умногоме имали подршку у становништву, које је већ пружало организован отпор Турцима. ${ }^{4}$ На основу тога поткрај септембра 1689. заузет је Ниш, а потом Прокупље и Приштина а до краја октобра и Скопље. Те успехе постигао је наследник принца Лудвига Баденског, генерал гроф Енеја Силвије Пиколомини, који се, запаливши окужено Скопље, упутио у Призрен где се 6. новембра састао са пећким патријархом Арсенијем III Чарнојевићем, али је изненада и сам покошен кугом умро три дана после тога. При томе је пред смрт примио причешће од истог „шизматичног патријарха“. 5

Нови командант царске војске Георг Кристијан херцег од Холштајна амбициозно се вратио на ратиште у северној Македонији и спалио Штип, а потом стигао и до Велеса. Међутим, 1. јануара 1690. био је од Турака поражен у

\footnotetext{
${ }_{3}^{3}$ Алекса Ивић, Историја Срба у Војводини, Нови Сад 1939, 275, 489.

${ }^{4}$ Један од организатора устаничке војске у Србији и Влашкој био је и гроф, барон Ђорђе Бранковић. Он је организовао скоро 30.000 устаника под својом командом. Ухапшен је ускоро у јесен 1689. од стране принца Лудвига Баденског услед његових нараслих претензија за стварање сопствене независне словенске државе (Илирика), као и откривених веза са руским двором. Више о грофу и барону Ђорђу Бранквићу у: Јован Радонић, Гроф Ђорђе Бранковић и његово време, Београд 1911, passim; Милан Чуљак, Српски грофови Бранковићи, Зборник Матице српске за историју 57, Нови Сад 1998, 7-46; Владан Гавриловић, Дипломатички списи код Срба у Хабзбурикој монархији и Карловачкој митрополији од краја XVII до средине XIX века, Ветерник 2001, 100-102; Милан Чуљак, Бранковић, Борђе, Српски биографски речник 1, Нови Сад 2004, 784-789; Владан Гавриловић, Српско племство у Хабзбуршкој монархији од XVI до прве декаде XVII века, Истраживања 17, Нови Сад 2006, 35-53; Јелка Ређеп, Гроф Ђорђе Бранковићидеја о стварағу српске државе, Зборник радова „Државотворна идеја тројице српских великана: Грофа Ђорђа Бранковића, Доситеја Обрадовића и Саве Текелије“, Темишвар 2012, 135-147.

${ }_{5}^{5}$ Гроф Енеја Силвије Пиколомини је добио задатак од принца Лудвига Баденског у лето 1689. да преко Старе Србије и Албаније продре на Јадранско море и да тиме одсече Босну и Херцеговину од остатка Турске. За тај немали задатак, смањена царска војска је требала хитну сарадњу са српским и албанским становништвом, као и са патријархом Арсенијем III Чарнојевићем, што је Пиколомини чинио веома добро, не вређајући народ, његове обичаје и веру. На основу тога је и дошло до патријарховог повратка из Никшића и сарадње са Пиколоминијем (Јован Томић, Срби у Великој сеоби, (репринт), Београд 1990, 134-146; А. Ивић, Историја Србау Војводини, 279-284).
} 
Качаничкој клисури, после чега је отпочело опште повлачење царске и српске устаничке војске према Нишу и Београду. Ратовање је настављено, али у мањем обиму, а потом је дошло до затишја у коме су се Турци припремали за офанзиву а царска војска и српски одреди за дефанзиву. ${ }^{6}$ У исто време отпочела је прва етапа Велике сеобе, коју је Алекса Ивић на основу грађе бечких архива приказао следећим речима:

„У оним крајевима из којих су потиснули хришћанске чете, Турци су љуто кажљавали староседеоце хришћане због учињеног неверства. Приштину и њену околину... Турци су спалили и све одрасле људе поубијали, а младиће одвели у ропство. Вест о свирепом поступку Турака спрам Срба раширила се по целој Србији те се народ кретао према Дунаву и Сави, не смејући да дочека турску војску. Усред зиме повлачили су се старци, жене и деца, гонећи своју марву и носећи своје ствари... Повлачили су се, даље, српски становници у пределу од Приштине до Скопља, Призрена и Пећи... Повлачили су се и бегали испред Турака Срби из свих оних предела, у којима се је најдуже задржавала аустријска војска и у којима су се одигравале недавне борбе, јер је то становништво, хтело не хтело, било увучено у сарадњу са хришћанима и учествовало у прављењу магазина и у превозу хране и муниције... те се тиме компромитовало у очима дотадањих господара Турака. У масама су се повлачили становници из јужних предела, из околине Скопља, Трепче, Вучитрна и Приштине, јер су њихове кривице биле најсвежије и на њих су Турци наишли у првој срџби... Бегунци су узимали правац према Београду и Сави, пошто су се Темишвар и околина налазили у турским рукама, те је лева обала Дунава била угрожена од Турака... Ван сваке је сумње, да је велики проценат избеглица платио главом услед напорног пута. По снегу, студени и киши месецима проводити и под отвореним небом дањивати и ноћивати, могли су само снажни и здрави људи, а нејака деца, немоћни старци и болешљиви људи и жене су подлегали огромним патњама. Многи одрасли људи били су принуђени, да уз пут оставе своје породице њиховој судбини и да ступају у проређену аустријску војску“. 7

Почетком пролећа 1690. избеглице из јужне и југоисточне Србије задржале су се у Београду и на обали Саве, верујући да ће царска војска поново потиснути Турке и омогућити им повратак у завичај. Међутим, до тога није дошло јер су се ослабљени „ћесаревци“ и даље повлачили пред Турцима који су средином августа поразили Аустријанце у Ердељу, а у Србији се приближили Нишу, чија је посада капитулирала 8. септембра, с тим што су немачки војници из нишке посаде пуштени да се повуку у Београд а сви Срби били препуштени Турцима који су их без милости поубијали, у свему преко 4.000 душа. ${ }^{8}$ После тога Турци су продужили са освајањем Источне Србије, ускоро избили на Дунав, а поткрај септембра почели су са опсадом Београда, у који су ушли 6. октобра 1690. године. Разбежало се и оно мало

\footnotetext{
${ }^{6}$ А. Ивић, Историја Србау Војводини, 285-288.

${ }^{7}$ Исто, 288-289.

${ }^{8}$ Клаузула о несметаном проласку нишке посаде се односила и на Србе, које су Турци безобзирно издвојили и побили. Турци су то учинили из обести и освете према српском народу који се прикључио Хабзбурзима (А. Ивић, Историја Срба у Војводини, 293-295; Радослав Грујић, Са Арсенијем III на челу, Зборник „Велика сеоба“, Београд 1990, 44).
} 
аустријских јединица које су остале под командом мађарског капетана Владислава Чакија, који је имао задатак да брани србијанску обалу Саве, и при томе је Чаки прешавши у Срем вршио небројена пустошења, да би се крајем октобра пребацио с тим јединицама царске војске у Бачку. ${ }^{9}$

У међувремену, од пада Ниша до почетка опсаде Београда, изведена је друга фаза Велике сеобе. Први исељеници кренули су већ почетком септембра и преплавили Срем, а кад се чуло за бекство Чакија и његових хусара, међу избеглицама је настала неописива паника, па је свако желео да што пре напусти Срем и домогне се Бачке и Барање. А да би се дошло до њих, ишло се преко понтонских мостова код Петроварадина и Осека, а потом обема обалама Дунава према северу. Патријарх Арсеније Чарнојевић са тројицом епископа и са калуђерима избегао је лађама до Сентандреје а затим до Коморана. ${ }^{10}$ Највећи део избеглица зауставио се на простору од Будима до Коморана, на пустој Сентандреји, у Острогону, Ђуру, делимично и у Јегри, Токају, Сатмару, Великом Варадину. Знатан део пак застајао је и успутно се задржавао и насељавао у Бачкој, око Суботице, Сегедина, Баје, затим у Барањи и на подручју од Осека до Будима, у Шиклошу, Мохачу, Капошвару и у њима околним селима. Њихови збегови су настајали најчешће у предграђима тих градова или пак на отвореним ливадама. ${ }^{11}$

У историјској науци било је много спорења око броја миграната у Великој сеоби. Полазило се од хроничарског записа калуђера Стефана Раваничанина, према коме је патријарх Арсеније Чарнојевић (Црнојевић) „просил цесарја [Леополда I], да би в державу јего с народом сербским преселили сја““, што је цар одобрио и „тогда в пролетнјеја [sic!] времја подвиг сја патријарх са множеством народа сербскаго 37.000 фамилија и толико во војенију службу цесарју вступили... Тогда же и от многих манастиреј калугери и прочи мирски, мужески пол и женски преселиша сја в Сремје, в Славонији, в Бачку, и до Будима простирали сја. И бист наш пут хожденуја 40 днеј. И придохом в нјекоје мјесто више Будима зовомо Сент-андрија“. ${ }^{12}$ Други хроничар Атанасије Србин не наводи број избеглих Срба, него само констатује да после издаје команданта Београда, генерала Француза, „Срби уђоше сви у чамце. И

\footnotetext{
${ }^{9}$ О бекству Чакија са положаја је јавио Дворском ратном савету у Бечу царски генерал Аспремон у писму следеће садржине: „General Chiaki von Cupina wieder die gehabte Ordre begeben, der er wider contramandirt und die anderte Gränizer nacher Mitroviz zu gehen beordert“" (А. Ивић, Историја Срба у Војводини, 296).

${ }^{10}$ Преко ових мостова прелазили су Срби у Бачку и Барању па су ишли уз Дунав према Будиму. Неки су ишли на колима, други на коњима, неки на лађама, а многи су ишли и пешке, нарочито они који су са собом гонили марву. Барањом уз Дунав кретао се и патријарх Арсеније са три епископа: рудничким Теофаном, зворничким Герасимом и београдским Симеоном, и са многим калуђерима (Алекса Ивић, Нада у повратак, Зборник „Велика сеоба“, 46).

${ }^{11}$ Средиште српских избеглица било је у околини Будима, на потесу до опустелог месташца Сентандреје. Тако је заповедник Будима барон Арејцага у свом писму од 9. новембра 1690. известио Дворски ратни савет да је у околину Будима дошло 15.000 српских бегунаца. Сам патријарх се првобитно зауставио у Сентандреји, у којој је оставио део народа и сву тројицу епископа, а он пође даље и настани се за прво време у Коморану, где се већ из ранијих времена налазила српска црква и православна црквена општина (А. Ивић, Историја Срба у Војводини, 296-298; А. Ивић, Нада у повратак, 47-48).

12 Љубомир Стојановић, Стари српски записи и натписи, књ. III (репринт издање), Београд 1984, 94, записи бр. 5283, 5284.
} 
би чамаца до десет хиљада. И побегоше реком Дунавом уз воду и дођоше под град Будим, који је под цесаром. А под Турцима нико од Срба не оста, но сви ћесару потчинише се око реке Дунава и по другим градовима“. ${ }^{13}$

Историчар Каменко Суботић о целокупном пресељавању изрекао је овакав суд: „Повлачило се на све стране; сеоба се није од једном догодила; као што је трајала за целог рата, исто тако се није збивала на једном месту. Карактер ове сеобе је растрешеност; народ се није преселио једном одлуком ни вољом, он је на територијум друге државе прелазио кад су га генерали позвали, или кад је догорело до ноката... Главни моменат траје од почетка године 1690. До у јесен исте, а сеоба се кретала од Старе Србије до Сентандрије“. ${ }^{14}$

Старији историчари, осим Илариона Руварца, узимали су Раваничанинов исказ о 37.000 породица као меродаван и истинит, док су историчари XX века вредност тог исказа оспоравали и уместо броја породица тврдили су да реч може бити само о 30.000-40.000 душа. Не улазећи у подробнију анализу супротстављених мишљења, изнећемо само најважнија, која се заснивају на казивању Стефана Раваничанина, а потом ћемо саопштити изворне архивске податке и мишљења савремених историчара.

Немајући других извора, већ први српски историчар у XVIII веку, Павле Јулинац, у свом делу Краткоје введеније в историју происхожденија Славеносербског народа (1765) прихватио је Раваничанинов исказ као веродостојан, док је много значајнији од њега, Јован Рајић, без коментара, само констатовао: „Повјествујетсја, что тогда 37.000 фамилија прешло у аустријске царске земље“. За њим се повео Александар Стојачковић, у романтичарском претеривању пишући следеће: „И овде 37.000-40.000 Србски фамилија, најмање по милиона душа, под предводителством свога патријарха Арсенија III Чарнојевића, премда нечовештвом турским принуђени, то опет с тесним грудна и сузним очима оставе премило и пресвето отечество своје, оставе најрођенију земљу и свог бића колевку, оставе освећене гробове праотаца своји, и пређу у царске земље, у тој надежди, да ће јоште толико хиљада застати с Деспотом Бранковићем у војски фелдмаршала Баденског... Овако населивши се из старог отечества свог Србији, немјесте се по Срему и Славонији, око Осека, по Бачкој, и около Будима и Ст. Андреје у селу Помазу, Калазу, Чобанцу и Збегу“. ${ }^{15}$

Стојачковића је следио аустријски етнограф и историчар Карл фон Церниг, пишући да је патријарх Чарнојевић у царске земље прешао са 40.000 породица, али додавши, ипак, да је уобичајени податак о преласку 36.000 породица које су биле из Србије, Рашке, Босне, Албаније и Влашке, а населиле се делом између Саве и Драве, посебно у Малу Влашку у Славонији и у Срему, затим у Бачку, па делом у Јенопољски округ око Тисе и Мориша, делом у Коморан и Будим и Сентандреју. На другом месту у својој књизи изричито је нагласио да је реч о 36.000 породица, али да

\footnotetext{
${ }^{13}$ Атанасије Србин, Опустошења српске земље, Зборник „Велика сеоба“, 26.

${ }^{14}$ Каменко Суботић, O идеји Српске Војводине и народно-ирквене аутономије на кониу XVII века, Летопис Матице српске, књ.183, Нови Сад 1875, 42.

${ }^{15}$ Александар Стојачковић, Черте народа србског у унгарским областима, Беч 1849, $27-28$.
} 
је нових 6.000 српских породица прешло у следећих десет година (1690-1700) и населило се у Бачку, у Пештанску ћупанију, Малу Влашку, Куманско Поље. ${ }^{16}$ Насељавање, односно попуњеност српског народа на тлу Јужне Угарске је било у толиком обиму да су се према Цернигу, од Велике сеобе и у току прве половине XVIII века, Вуковарска, Сремска и Торонталска жупанија у обичном говору називале Србијом (Рашком). ${ }^{17}$

Већу тежину имало је писање о Сеоби знаменитог историчар о Србима у XVIII веку, Јохана Хајнриха Швикера, према којем је патријарх Арсеније Чарнојевић преко границе превео „цео један народ... од 37.000 до 40.000 породица“, о чему је патријарх и лично посведочио. Ти емигранти састојали су се највише од жена, деце и стараца и свештеника, а пребачени су даље у унутрашњост земље, док су млађи и способнији задржани на ратишту. Избеглице, највећим делом, нису добијале дозволу да уђу у градове, него су најчешће боравиле под шаторима изван насеља. Градови нису повољно гледали на бегунце без отаџбине, али су мушкарци ипак примани у тврђаве у којима су вршили војничке службе. ${ }^{18}$ Своје мишљење о броју миграната Швикер је објаснио тиме да су те бројке заиста више пута оспораване, да изгледају необично велике, али ако се узме у обзир да је српска породица у просеку онда имала 15-20 глава, односно да ако се барата само са просеком од 10 глава по породици, добија се импозантна цифра од 370.000 до 400.000 душа. Како даље наводи Швикер, због спремности Срба на исељавање и због страха од Турака у том тренутку, због подизања устанка, изгледа, ипак, да та бројка није немогућа. Поред тога чињенице говоре да је исељавање било врло значајних размера. Подручје Старе Србије било је због тога скоро сасвим депопулисано, полуопустело, а потом запоседнуто од стране надирућих Арбанаса. Најзад, и накнадна досељавања Срба у Монархију у времену од 1690 . до 1700 . године била су врло јака. ${ }^{19}$

Са мишљењем Швикера сагласили су се и историчари Емил Пико и Стеван Павловић, који су писали да Срби у Угарску „дођоше на броју од 35.000 до 40.000 породица, односно да тиме претпоставке о броју од 400.000 до 500.000 глава пресељених у Угарску неће бити превише узнесен, и то стога што су српске породице-задруге понекад износиле и до 40 чланова“. ${ }^{20}$

Наведене процене о броју породица у Сеоби прихватили су такође хрватски историчар Таде Смичиклас који у свом делу о ослобођењу Славоније говори о „37.000 фамилија“ ${ }^{\text {‘21 }}$, као и тадашњи млади српски историчар Аврам Ђукић који каже да је запазио како „Срби држе да је патријарх Арсеније III прешао са 36.000 до 40.000 породица из Старе Србије у Мађарску и Славонију 1690. године“. ${ }^{22}$ У истом

\footnotetext{
${ }^{16}$ Karl Freiherr von Czoernig, Etnographie derOsterreichischer monarchie, band. II, Wien 1857, $157,306$.

17 „Von diesen rascischen Einwanderern wurden die drei Komitate Posega, Valko und Syrmien, wie auch das Torontaler Komitat, seit Ende des sechzehnten Jahrhunderts und noch in der ersten Hälfte des vorigen Jahrhunderts im gemeinen Sprach-gebrauche Rascien (Rascia) genannt“ (K. F. von Czoernig, Op. cit., 161).

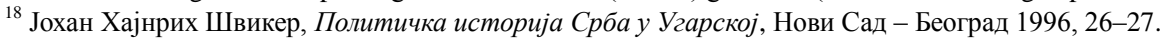

${ }^{19}$ Исто, 26.

${ }^{20}$ Стеван Павловић, Срби у Угарској (превод истоименог дела Емила Пикоа), Нови Сад 1883, 80.

${ }^{21}$ Tade Smičilkas, Dvijestogodišnjica oslobođenja Slavonije, Zagreb 1891, 155.

22 Љубисав Андрић, Сеоба у споровима, Зборник, текст Аврама Ђукића о Сеоби, Нови Сад 1991, 5.
} 
тексту на другом месту, Ђукић у својим разматрањима о Сеоби иде и корак даље наводећи, између осталог, и Пикоа и његово дело о Србима у Угарској, да су постојала два таласа Сеобе, један мањи 1690. и чак много већи 1694. године. ${ }^{23}$

Оваква размишљања је веома оштро напао, на себи својствен начин, па чак и иронично у многим стварима, неприкосновени Иларион Руварац. Полазећи од сведочења савременика Сеобе, као првог „оног бедног и невољног скитача Стефана Раваничанина“, према коме је патријарх Арсеније превео 37.000 породица, Руварац доказује да су историчари, почевши од Јулинца преко Рајића, Енгела, Стојичковића и Цернига до Аврама Ђукића, „олако и некритички преузимали наведени Раваничанинов податак, те да су се сви они колебали о броју породица између 30.000 до 40.000, а да су црногорски владика Василије Петровић, Милорад Медаковић и Марко Драговић дотерали и до 80.000 породица, или скоро до милион душа“. Супротстављајући се свима због преувеличавања броја пресељеника, Руварац се позвао на компетентност статистичара Кнежевине Србије Владимира Јакшића, који је дошао до закључка да „оних 37.000 породица тешко да су више од 100.000 душа бројале, почем је искуством доказано да су породице приликом сеоба слабо бројне, а и тиранска влада у Турској не допушташе никада да се народ нормално намножи“. Али Руварац се не задовољава ни овим резоновањем него се осврће и на два компетентна сведочанства из доба патријарха Чарнојевића. У првом изричито се каже да се „епископ Срба (Раца) већ после губитка Београда са 20. до 30.000 душа ставио под царску заштиту“. У другом примас Угарске, кардинал Леополд Колонић, у писму папи Клименту XI из децембра 1703. говори о више од 60.000 глава које су из турског ропства прешле под варску заштиту“, а које би он радо превео на унију. Руварац се, најзад, позива и на самог патријарха Чарнојевића који у представци цару Јосифу I из 1706. каже да је из Турске превео „много хиљада душа као и око 40.000 душа из Влашке“. На основу тих сведочанстава, узимајући у обзир да је са патријархом изгледа директно прешло 20.000 до 30.000 душа, као и оних 40.000 из Влашке, Руварац закључује да се укупан број пресељених Срба у угарске земље може проценити на 70.000 до 80.000 душа. $^{24}$

По мишљењу историчара Душана Поповића, као најверодостојније сведочанство о броју пресељених Срба могло би се узети оно које је кардинал Колонић навео у писму папи: више од 60.000 до 70.000 душа, што је „за оно време, број веома висок, а коме у прилог иде и чињеница да су Стара Србија и Метохија готово опустеле, нарочити област око Приштине, Трепче, Вучитрна“. Поповић своје разматрање о Сеоби потврђује тиме што је нарочито око Приштине разорено и попаљено око 360 великих и малих српских села. Наводи такође да је пострадало српско становништво Косова, Прилепа, Скопља, а опустели су и Шумадија и Поморавље. Срби избегли у Будим били су претежно из Зете, Београда, Рудника, а они у Сентандреји из Београда, Пожаревца, Ћипровца и Срема, док су најближу

\footnotetext{
${ }^{23}$ Исто, 9-12.

${ }^{24}$ Иларион Руварац, Одговор на питање, Зборник „Сеоба у споровима“, 14-30; Славко Гавриловић, Иларион Руварач и Велика Сеоба 1690, Зборник радова „Браћа Руварац у српској историографији“, Нови Сад - Сремска Митровица 1997, 46-47.
} 
околину патријарха Чарнојевића чиниле избеглице пореклом из Старе Србије и Метохије. $^{25}$

Историчар Глигор Станојевић у свом познатом делу Србија у време бечког paта претпостављени број избеглица према мишљењу Душана Поповића сматрао је претераним, односно „да би требало број проценити на 30.000 душа, јер о толикој цифри говори сам патријарх, а да се сви миграциони таласи у време Бечког рата српског народа, са онима из Босне, које је довео 1688. принц Савојски, могу проценити на максимум 70.000 људи“. ${ }^{26}$

Историчар Стеван Михалџић се није бавио конкретном цифром избеглих Срба у време Сеобе него територијом на којој се она по његовом мишљењу највише одражавала. Како наводи, „сва српска сеоба 1690. године изручи се на предео Барање, Толне и Шомођа у језгру своме, а окрајци се простреше и на жупаније Васпремске, Столно Београдске, Ђурске и Коморанске, у којима је већ одраније постојала већина српског становништва“. ${ }^{27}$

Наводимо мишљење још двојице историчара XX века, Димитрија Богдановића и Николе Самарџића. Богдановић је полазећи од Раваничаниновог записа, као наводно најпоузданијег историјског извора, закључио да је патријарх у Аустрију превео „око 37.000 српских породица, што значи најмање 185.000 душа“. ${ }^{28}$ С друге стране Самарџић доноси досад незабележен податак да је, према вести из Беча од 13. априла 1696. објављеној у Ротердаму, патријарх Чарнојевић изјавио да је после пада Београда „прешао у Аустрију са 30.000 људи“ и да је цару Леополду на располагање ставио исто толико извежбаних војника. На основу тога и других података, Самарџић је закључио да се број миграната с патријархом може процењивати на 30.000-40.000 душа. ${ }^{29}$

У архивским изворима можемо само посредно говорити о броју избеглих Срба у време Сеобе, јер нема директног извора са највишег места који би поуздано могао да одговори на то питање. Према посредним изворима број се кретао између 20.000-40.000 душа. На пример, будимски коморски администратор Јохан Штефан фон Верлајн је јавио 16. октобра 1690. дворској комори у Бечу да је „стигло одоле 20.000 Раца“. 30 Мало пре овог датума, 13. октобра 1690, Скупштина Коморанске жупаније је јавила Дворском ратном савету у Бечу да се у Коморану налазе људи из разних крајева, наиме Срби (Рашани), Бугари, Далматинци, Јермени, који својим присуством могу угрозити турске посланике на њиховом путу за Беч. Такође 18. октобра 1690. Сенат града Коморана се жалио да су „Расцијани из разних места

\footnotetext{
25 Душан Ј. Поповић, Велика сеоба Срба, Београд 1954, 40-42.

${ }^{26}$ Глигор Станојевић, Србија у време бечког рата, Београд 1976, 190-191.

${ }^{27}$ Ове наводе потврђују извори из Будимске коморске администрације по којима је она 20. априла 1691. опоменула Васпремску жупанију да поштује царску одлуку о ослобађању од свих терета избеглих Срба (Стеван Михалџић, Барања, Нови Сад 1937, 281; Славко Гавриловић, Иван Јакшић, Извори о Србима у Угарској с краја XVII и почетка XVIII века, књ. I, Београд 1987, 72).

${ }^{28}$ Димитрије Богдановић, Кривотворење истине, Зборник „Сеоба у споровима“, 333.

${ }^{29}$ Никола Самарџић, Странции о Сеоби, Зборник „Сеоба у споровима“, 486.

${ }^{30}$ Славко Гавриловић, Извори о Србима у Угарској с краја XVII и почетка XVIII века, књ. II, Београд 1990, 69.
} 
доњих крајева дошли и населили се у град, као и да стално долазе нови, те да могу угрозити јавну безбедност“. 31

Такође, сам патријарх Чарнојевић је у више наврата крајем октобра и почетком новембра 1690. обавештавао председника Угарске дворске канцеларије у Бечу Блажа Јаклина како се са њим у Острогону, Коморану и Будиму налази више од 30.000 душа, односно избеглица са женама и децом, које су опљачкане, голе и босе. ${ }^{32}$ Почетком новембра 1690. командант Будима, генерал Јозеф Арејцага, писао је Дворском ратном савету у Бечу да је у његов округ стигло 15.000 душа српске нације (15.000 Sehlen) којима је коморски инспектор дозволио да се сместе у насеља од Старог Будима до Вишеграда и Острогона. ${ }^{33}$ Из дописа Будимске коморске администрације од 3. децембра види се да су се у Сентандреји из Београда и других места поред православних Срба населили и „католички Раци“. 34

Управо то помињање Раца (Срба) католика омогућило је кардиналу Леополду Колонићу да 1706. године, признајући број од 40.000 душа, умањи патријархову заслугу, наводећи да су се позиву цара Леополда упућеном балканским хришћанима управо највише одазвали првенствено католици и да су они већином и прешли у аустријске земље, што наравно не одговара историјској истини. ${ }^{35}$

Навођењем оваквих података који се налазе у архивским изворима, можемо закључити да извори говоре о главној групацији миграната на челу и око патријарха Чарнојевића која је износила 30.000-40.000 људи, не рачунајући оне хиљаде које су се на путу према Будиму и Коморану задржавале и настањивале по Бачкој, Срему, Источној Славонији, Барањи и дуж Дунава, до ниже Будима.

О Великој сеоби Срба из 1690. дуго ће се још, ако не и непрестано, писати у српској и у европској историографији, али број избеглих Срба никада неће тачно бити утврђен. Мишљења смо да је најближа реалности процена великог историографа Илариона Руварца од 70.000 до 80.000 душа избеглих у време Сеобе, а то је за крај XVII века врло импозантна бројка.

Извори и литература:

Гавриловић, Славко - Јакшић, Иван, Извори о Србима у Угарској с краја XVII и почетка XVIII века, књ. I, Београд 1987.

Гавриловић, Славко, Извори о Србима у Угарској с краја XVII и почетка XVIII века, књ. II, Београд 1990.

Hoff kriegs archiv, Hoff finanz Ungarn (HKA, Hoff.Ungarn) r. N ${ }^{0} 325$, October 1688, fol. 230.

Стојановић, Љубомир, Стари српски записи и натписи, књ. III (репринт издање), Београд 1984.

Czoernig von Freiherr, Karl, Etnographie derOsterreichischer monarchie, band. II, Wien 1857.

\footnotetext{
${ }^{31}$ А. Ивић, Историја Срба у Војводини, 493.

${ }^{32}$ С. Гавриловић, Извори о Србима у Угарској с краја XVII и почетка ХVIII века, књ. II, 70.

${ }^{33}$ А. Ивић, Историја Срба у Војводини, 494.

${ }^{34}$ С. Гавриловић, И. Јакшић, Извори о Србима у Угарској с краја XVII и почетка XVIII века, књ. I, 52.

${ }^{35}$ С. Гавриловић, Извори о Србима у Угарској с краја XVII и почетка XVIII века, књ. II, 687-688.
} 
Литература:

Атанасије Србин, Опустошења српске земље, Зборник Велика сеоба, Београд 1990.

Богдановић, Димитрије, Кривотворење истине, Зборник „Сеоба у споровима“, Нови Сад 1991.

Гавриловић, Владан, Дипломатички списи код Срба у Хабзбуршкој монархији и Карловачкој митрополији од краја XVII до средине XIX века, Ветерник 2001.

Гавриловић, Владан, Српско племство у Хабзбуршкој монархији од XVI до прве декаде XVII века, Истраживања 17, Нови Сад 2006.

Гавриловић, Славко, Иларион Рувараи и Велика Сеоба 1690, Зборник радова „Браћа Руварац у српској историографији“, Нови Сад - Сремска Митровица 1997.

Грујић, Радослав, Са Арсенијем III на челу, Зборник „Велика сеоба“, Београд 1990.

Ђукић, Аврам, Време сеобе, Зборник „Сеоба у споровима“, Нови Сад 1991.

Ивић, Алекса, Миграције Срба у Хрватску током 16, 17. и 18. столећа, Суботица 1923.

Ивић, Алекса, Историја Срба у Војводини, Нови Сад 1939.

Ивић, Алекса, Нада у повратак, Зборник „Велика сеоба“, Београд 1990.

Павловић, Стеван, Срби у Угарској (превод истоименог дела Емила Пикоа), Нови Сад 1883.

Поповић, Душан Ј., Велика сеоба Срба, Београд 1954.

Радонић, Јован, Гроф Ђорђе Бранковић и његово време, Београд 1911.

Ређеп, Јелка, Гроф Ђорђе Бранковић - идеја о стварању српске државе, Зборник радова „Државотворна идеја тројице српских великана: Грофа Ђорђа Бранковића, Доситеја Обрадовића и Саве Текелије“, Темишвар 2012.

Руварац, Иларион, Одговор на питање, Зборник „Сеоба у споровима“, Нови Сад 1991.

Самарџић, Никола, Странци о Сеоби, Зборник „Сеоба у споровима“, Нови Сад 1991.

Smičilkas, Tade, Dvijestogodišnjica oslobođenja Slavonije, Zagreb 1891.

Станојевић, Глигор, Србија у време бечког рата, Београд 1976.

Стојачковић, Александар, Черте народа србског у унгарским областима, Беч 1849.

Суботић, Каменко, O идеји Српске Војводине и народно-ирквене аутономије на кониу XVII века, Летопис Матице српске, књ.183, Нови Сад 1875.

Томић, Јован, Срби у Великој сеоби (репринт), Београд 1990.

Чуљак, Милан, Српски грофови Бранковићи, Зборник Матице српске за историју 57, Нови Сад 1998.

Чуљак, Милан, Бранковић Ђорђе, Српски биографски речник, књ. 1, Нови Сад 2004.

Швикер, Хајнрих Јохан, Политичка историја Срба у Угарској, Нови Сад-Београд, 1996. 


\title{
THE VELIKA SEOBA OF THE SERBS AS A WAVE OF MIGRATION DURING THE GREAT VIENNA WAR
}

\begin{abstract}
Summary
This work presents various estimates of the number of Serbs relocated during the Velika seoba or Great Migration of 1690. The greatest problem which remains unresolved by historical research is the mention in some sources of large numbers of Serb families consisting of at least 7 to 10 members, thereby significantly affecting the tally of persons relocated at the end of the $17^{\text {th }}$ century. The estimated number of Serbs who migrated during the Seoba varies accordingly in the literature from 40,000 to 500,000. This work reviews the problem and the various positions regarding it which have been adopted by Serbian historiographers.
\end{abstract}

Keywords: Velika seoba, Great Migration of the Serbs, Great Vienna War, Serbs, Habsburg Monarchy. 